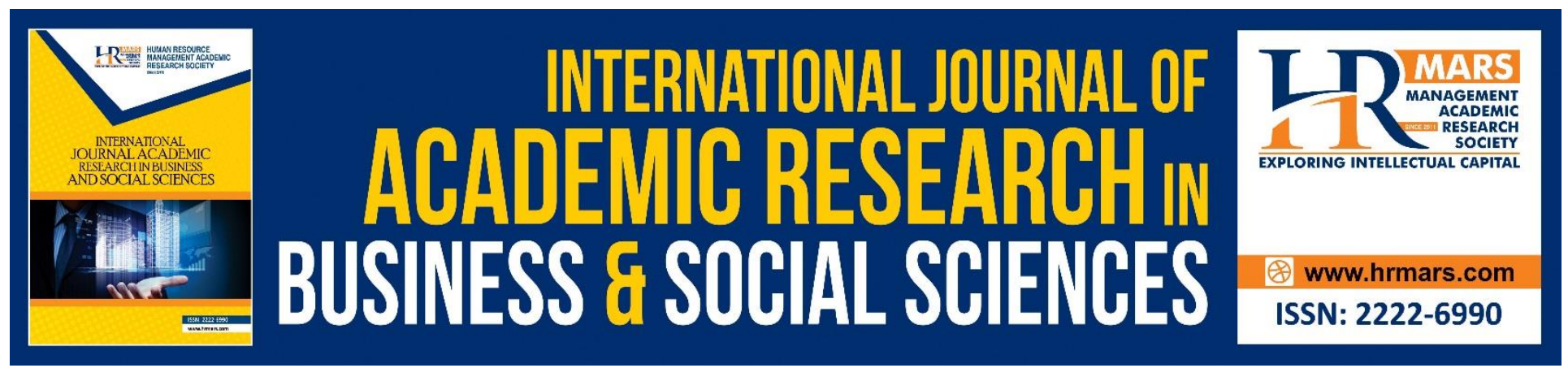

\title{
Managing, Profiling and Family Support of Malaysian Women Drug Abuse Inmates
}

Mohd Norbayusri Baharudin, Mahadzirah Mohamad, Fazida Karim

To Link this Article: http://dx.doi.org/10.6007/IJARBSS/v10-i5/7427

DOI:10.6007/IJARBSS/v10-i5/7427

Received: 10 March 2020, Revised: 14 April 2020, Accepted: 23 April 2020

Published Online: 29 May 2020

In-Text Citation: (Baharudin et al., 2020)

To Cite this Article: Baharudin, M. N., Mohamad, M., \& Karim, F. (2020). Managing, Profiling and Family Support of Malaysian Women Drug Abuse Inmates. International Journal of Academic Research in Business and Social Sciences, 10(5), 1008-1024.

\section{Copyright: (C) 2020 The Author(s)}

Published by Human Resource Management Academic Research Society (www.hrmars.com)

This article is published under the Creative Commons Attribution (CC BY 4.0) license. Anyone may reproduce, distribute, translate and create derivative works of this article (for both commercial and non-commercial purposes), subject to full attribution to the original publication and authors. The full terms of this license may be seen

at: http://creativecommons.org/licences/by/4.0/legalcode

Vol. 10, No. 5, 2020, Pg. 1008 - 1024

http://hrmars.com/index.php/pages/detail/IJARBSS

JOURNAL HOMEPAGE

Full Terms \& Conditions of access and use can be found at http://hrmars.com/index.php/pages/detail/publication-ethics 


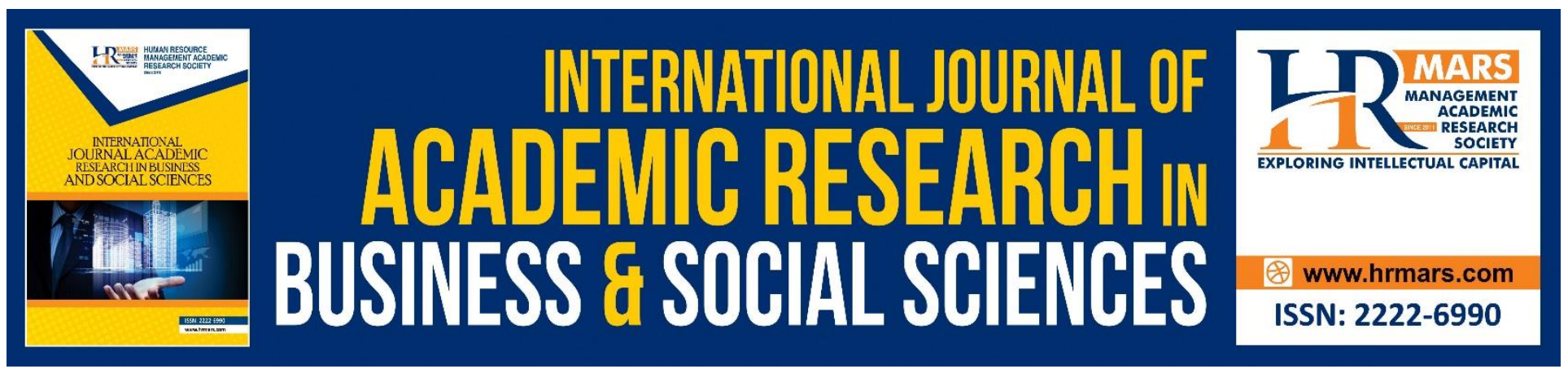

\title{
Managing, Profiling and Family Support of Malaysian Women Drug Abuse Inmates.
}

\author{
Mohd Norbayusri Baharudin, Mahadzirah Mohamad, Fazida Karim \\ Faculty of Business and Management, Universiti Sultan Zainal Abidin, Terengganu Darul Iman, \\ Malaysia
}

\begin{abstract}
Women engaging in the use of drugs have not only adverse effects on the country but also impose significant challenges in managing their incarceration and maintaining stable family structures. The review, therefore, aims to identify the approach of Malaysian Prison Department (PRIDE) in managing women's drug abuse inmates as well as to explore their addiction experiences and, to determine the extent of family relationships they have by applied quantitative approach and cross-sectional analysis. One hundred fifty women respondent selected from the random stratified sample of Kajang Women Prison, Selangor inmates. Data then analyzed by using descriptive analysis. Results from this study provide an insight into the practical method by PRIDE to reduce demand through drug treatment and rehabilitation and to reduce supply and improving detection. The results of the study showed that majority of the respondents were Malay, Muslim, age range between 31 to 40 years, highest education level at SPM/MCE/SPVM and still single. More than half of the respondents were self-employed with monthly income between RM1001.00 to RM2000.00. A majority had been imprisonment between two to five times, with six to ten years length of addiction and, methamphetamines become the most drug had been abuse. Finding also showed that the majority of drug inmates engaged in a high level of family relationship. Findings from this research yielded vast implications to improve drug abuse safety and security as well as treatment and rehabilitation programs, particularly among women drug abuse inmates in Malaysia.
\end{abstract}

Keywords: Family Support, Drug Abuse, Woman, Inmates, Prison.

\section{Introduction}

Women are an integral part of the nation's vital assets that contribute to the development of the country and community. Although Malaysian women have achieved such great success in the country's development, there are still many challenges and barriers that may affect women's role and status in moving forward such as their involvement in crime and drug abuse that have forced them entering prison. Being imprisonment is an unusual experience that requires a complex series of challenges. Usually, women inmates are subject to various layers of constraint and deprivation, both the intrinsic punishment imposed by all inmates and the patriarchal abuse of culture are they endure (Fehrmann, 2019). A report by World Female Imprisonment List in 2017 more than 714,417 women 
detained as pretrial detainees, remands or imprisoned and prosecuted in correctional facilities worldwide, representing $6.9 \%$ of the total population (Walmsley, 2015). In certain countries, including Malaysia, women inmates have increased significantly. Their life regulated by a set of regulations and laws as their activity closely monitored and recorded. They legally held, not voluntarily detained, which results in an unpleasant situation for most of them that correspond to their conduct (Mohamad et al., 2019; Mohamad, Ali, et al., 2017).

Malaysian Prison Department (PRIDE) reported there are 3,882 women inmates in 2017, 4,166 in 2018, and 4,373 in 2019, which more than half involved with drug cases (Jabatan Penjara Malaysia, 2020). It showed significant increases for the past three years. Currently, there are 20 institutions placed women inmates in various categories of offences all over Malaysia (Jabatan Penjara Malaysia, 2020). Most of them involved with drug-related laws consist of Dangerous Drugs Act 1952, Drug Dependants (Treatment and Rehabilitation) Act 1983, Dangerous Drugs (Special Preventive Measures) Act 1985, Dangerous Drugs (Forfeiture of Property) Act 1988 and Sale of Drugs Act 195 (Morgan \& Morgan, 2018). When serving their sentence, it is essential to gain support from others, especially from family members. A research finding by (Brannigan et al., 2002) proved that when family ties are active, the tendency for an individual to commit deviant behaviour becomes lesser. There is also evidence that supports the statement that it is essential to maintain and retain family ties that ensure strong positive influence to offenders upon release (Visher et al., 2011). Thus, family support during incarceration becomes a paramount factor in ensuring life free from crime.

\section{Literature Review}

Substance abuse has a detrimental impact on health, including poor living qualities and psychological issues (Mohamad et al., 2018) and, have a significant potential to twist abuser behaviour to criminal behaviour and delinquency because of drug misuse (Farrow \& French, 1986; Harrison \& Gfroerer, 1992; Kendler et al., 2019). Involvement of women with drug abuse often leads to social problems such as prostitution, moral collapse, and can lead to health problems such as HIV / AIDS infection (Wilson \& Kelling, 1982). Various factors contribute to behaviour crime and drug abuse (Mohd Nor et al., 2019). Previous scholars divided into two factors; social or environmental factors such as financial problem, lower level of education, family problems, and lack of religion practice (Austin et al., 1992; Basir, 2002) and, psychological factor such as mental illness, anxiety, depression and stress (Herrera, \& McCloskey, 2003; Putkonen et al., 2003; Zimmer-Gembeck \& Geiger \& Crick, 2005). Previous studies also proved that women substance abusers potentially have psychological problems (Alvarez et al., 2004; Boyas et al., 2019; Mann et al., 2004; Zimmermann et al., 2004). They might experience post-traumatic stress disorder (PTSD), depression, anxiety, affective bipolar disorder, phobias, psychosocial disorders and stress-related disorders (Back et al., 2011; Birkeland et al., 2017; Brady et al., 1998; Bremer-Landau \& Caskie, 2019; Goncharenko et al., 2019; Mendelsohn \& Sewell, 2004; Ronzitti et al., 2019).

Although cases of drug abuse among women showed a decline in their percentage, the impact of women's involvement in drug abuse activities need to be address seriously because they need to cope with stigmatization by public (Greenfield et al., 2007; Lal et al., 2015) due to failure to meet the aspirations and demands of life-related to women's moral principles. Besides, women involved with substance abuse are also considered by the community to be less functioning (Back et al., 2011; 
Chatham et al., 1999) to play a role in child care and the formation of a prosperous family (Davis, 1990; Ornoy et al., 2010). As a parent, she often fails to perform well (Cormier et al., 2004; Grella et al., 2008), lack emotional needs of children cannot be fulfilled (Moran et al., 2001), and children at risk for physical or mental abuse (Keen, 2000).

Past research has shown that the recovery process for substance misuse may involve family members, social-cultural and economic elements (Embleton et al., 2013). In determining the success of a drug addiction recovery, family institutions are the major institutions that need to play an essential role in the life of the addict especially in the process of recovery (Fauziah et al., 2012). The active engagement during the phase of recovery among family members produced more excellent outcome than those without family support (Foster et al., 2012). Lack of family support created problems with drug abuse treatment (Chie et al., 2015). Family support is an ongoing cycle between parents and children, and, between the siblings that occur in our everyday lives. There seems to be no precise definition for the family support, since the support provided by the family is comprehensive, including the physical and emotional aspects. (Fazillah et al., 2018), and, based on the literature, four supports commonly discussed; emotional support, information support, instrumental support and social championships (Toner \& Velleman, 2014). Many scholars looking into men inmates compared to women inmates and this scenario has contributed to a rich body of knowledge among men inmates and usually considered as the norm compared to women inmates (Fehrmann, 2019). There is a limited understanding of how women inmates undergo prison (Fehrmann, 2019), especially among women drug abuse inmates. These scenarios need to be tackle seriously, as the problem appears a negative impact on individuals, family institutions and the country.

PRIDE has implemented rehabilitation program for the women drug abuse inmates (Hashim et al., 2018), little is known about the framework of implementation by the department, the demographic and, the level of family support among women drug abuse inmates. With such information, probably it might provide relevant and beneficial information to the people and, to the community. Therefore, this study will discuss PRIDE experience in managing women drug abuse inmates, describing the experience of drug abuse inmates, and measuring the level of family relationships while undergoing rehabilitation programs in the prison.

\section{Methodology}

The structured of the recent study applied quantitative cross-sectional study, involves collecting data on a single sample of a population that is studied once based on existing respondents' attributes (Malhotra et al., 2007). The study also applied the descriptive analysis, as to describe the characteristics of variables (Hussin et al., 2014).

Participants - Women drug abuse inmates in Women Kajang Prison, Selangor, Malaysia selected as a participant for the study. The 182 sets of questionnaires distributed to the respondent using simple random sampling. The 150 of the inmates submitted the questionnaires. In this respect, the response rate was $82.42 \%$. 
INTERNATIONAL JOURNAL OF ACADEMIC RESEARCH IN BUSINESS AND SOCIAL SCIENCES Vol. 10, No. 5, May, 2020, E-ISSN: 2222-6990 @ 2020 HRMARS

Instruments - i) Women drug abuse inmates demographic - It contains questions related to the background and experience misuse of the drug. Respondents might make choices based on the statement of the item that best suits them. ii) Family relationship - Adapted from a Multidimensional Scale of Perceived Social Support (MSPSS) instrument consisting of 12 items (Zimet \& Gregory., 2016). For this study, only four items counted as it related to the family relationship by using a scale, 1 for strongly disagree to 10 for strongly agree. Composite reliability with greater than 0.6 is required. In this study, the reliability value obtained was 0.876 .

Statistical Analysis: Data were analyzed using the Statistical Package for the Social Science for Windows version 25 .

\section{Results and Analysis}

There are three main findings in this section. First, PRIDE experienced in managing women drug abuse inmates. Second, the demographics of women drug abuse inmates and third, the level of a family relationship while women drug abuse inmates were undergoing incarceration.

\section{Pride Experience}

Reducing demand through drug treatment and rehabilitation - Malaysian Prison Department (PRIDE) is a countrywide professional correctional entity. As a detention and rehabilitation agency, it has the consistency and pragmatic machinery and human resource strength to execute the vision, mission and objectives that related (Malaysia Prison Department, 2012). In order to reshape and modify the behaviour of inmates, the department introduced the Human Development Program (Morgan \& Morgan, 2018). As the holistic approach program, it has a specific module for women drug abuse inmates consisted of four phases aims to build a character of inmates, through an effective and efficient recovery system so that they can return to society as responsible and productive individuals based on the formation of attitudes, skills and knowledge.

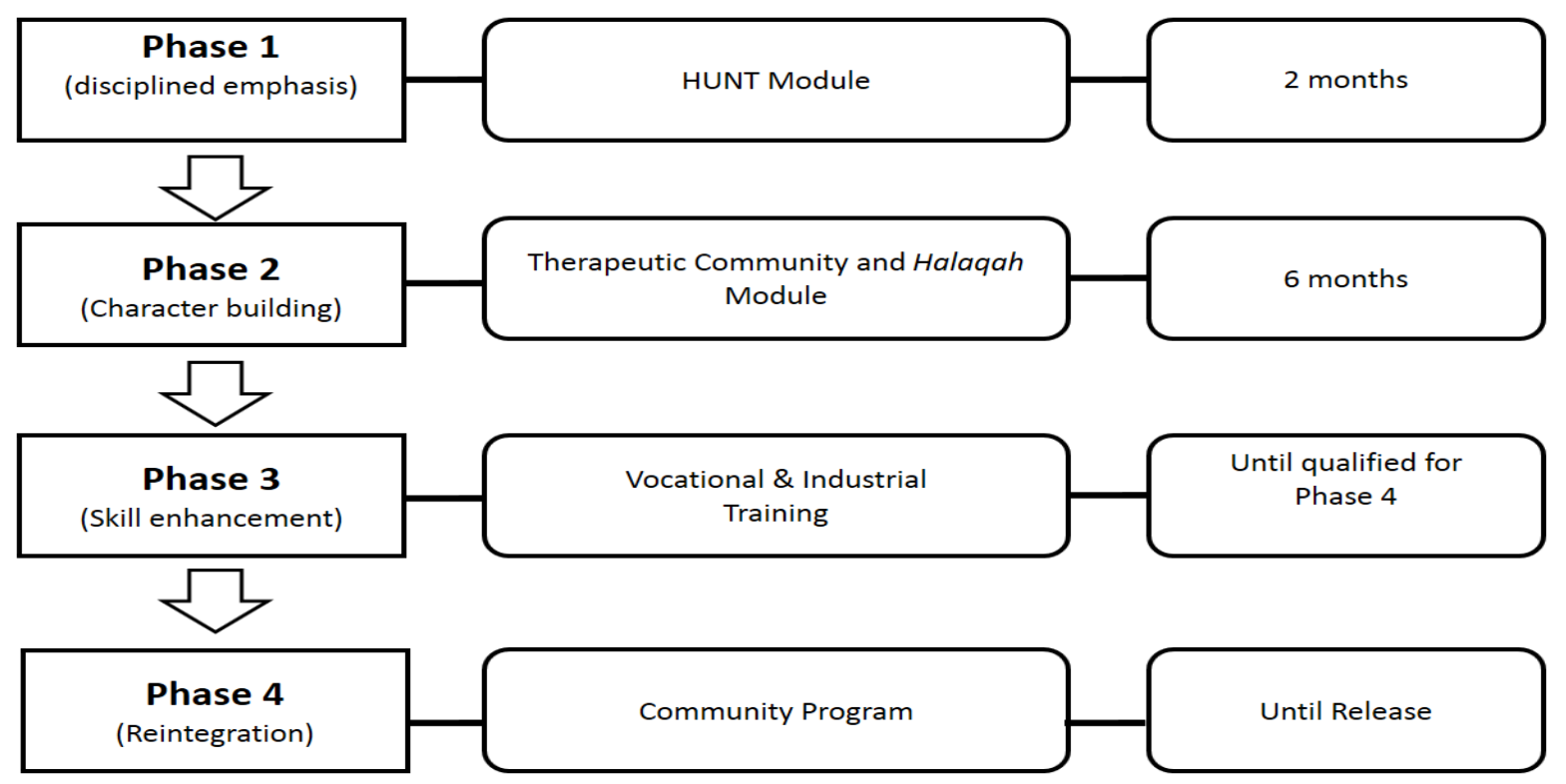

Figure 1. A framework of PRIDE drug rehabilitation program (Morgan \& Morgan, 2018) 
PRIDE staff have to make the distinction between short-sentence inmates (imprisonment less than six months) and long-sentenced inmates (imprisonment six months and above) as it affects the rehabilitation and treatment of female drug abuse inmates within the framework of the Human Development Program (Morgan \& Morgan, 2018). In phase 1, a psycho-education approach derived from the Substance Abuse and Mental Health Services Administration (SAMHSA, 1999). It requires female drug abuse inmates completing HUNT module acronym of "help yourself no suffer no tears", focusing on the early recovery rehabilitation (Morgan \& Morgan, 2018). In phase 2, they have to participate in either psychosocial approach, Therapeutic Community (TC) module or psycho-spiritual approach, Halaqah module (Morgan \& Morgan, 2018). The TC is a psycho-social approach applies a hierarchical peer pressure and recovery structure which represents enhanced personal and social responsibility (National Institute on Drug Abuse, 2016). It is applicable for female substance abuser treatment, role model concept, peer-to-peer, family-oriented for them to live together (De Leon \& Jainchill, 1991; Eliason, 2006; Fazly et al., 2019; Possick \& Itzick, 2018). Whereas Halaqah is a psychospiritual approach which strengthens female drug abuse inmates knowledge, practice and identity as Muslim through the fundamental concept of Islam (Dakir et al., 2015; Ibrahim, 2011; Morgan \& Morgan, 2018). After they go through the treatment for a minimum of six months, women drug abuse inmates qualify to proceed to phase 3 of vocational and industrial training. In a last stage of phase 4 , they might involve with community program until release (Morgan \& Morgan, 2018). The Human Development Program is a formal framework for all inmates and has a specific module for women drug abuse inmates where they need to perform in order to get a positive impact on their recovery process.

Reducing supply and improving detection - Drug is a severe issue in prison, have a demand and supply through transaction among inmates, staff and others visitor-related (King, 1991; Stevens, 1997). According to section 58 of Prison Act 1995, a person who smuggles or attempts to smuggle shall be liable to excellent not exceeding ten thousand ringgit or to imprisonment for a term not exceeding five years or to both (Laws of Malaysia, 1995). PRIDE performs various processes to track illegal drugs that smuggled into prison (Morgan \& Morgan, 2018).

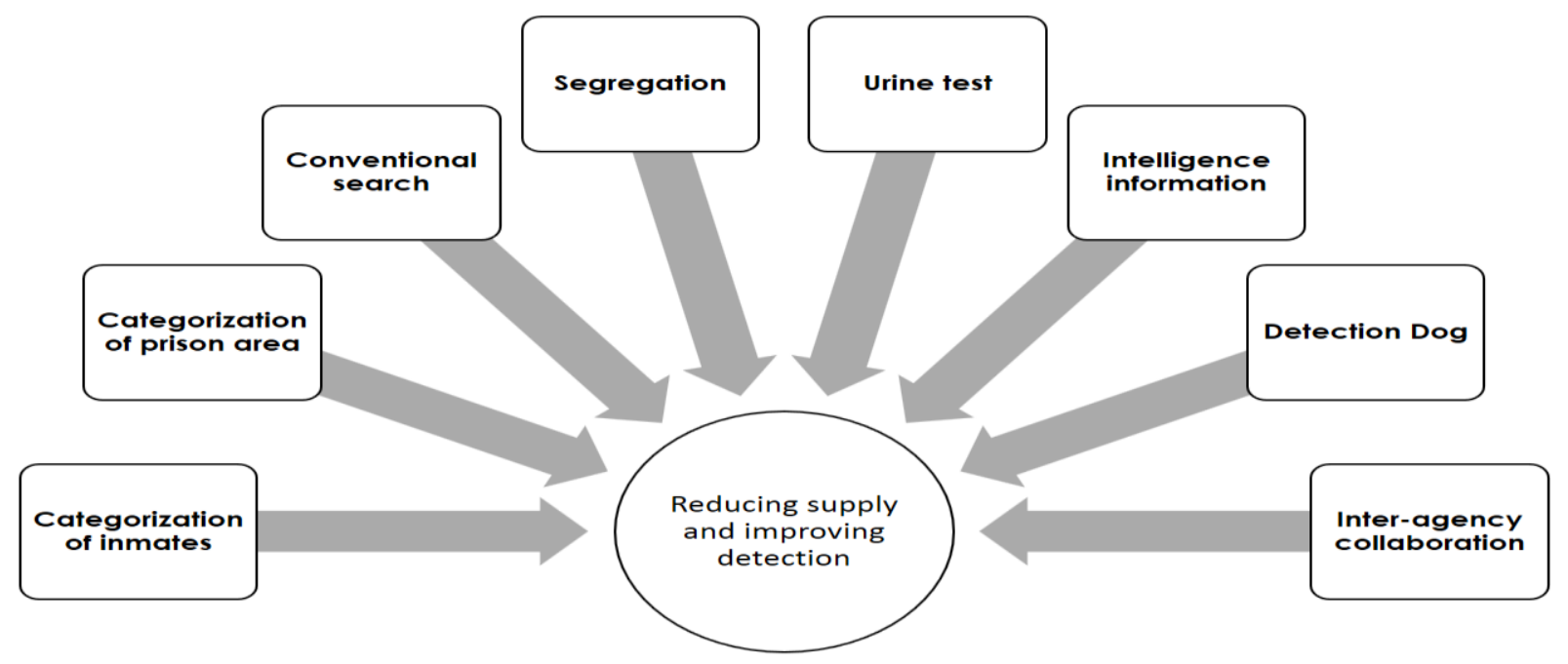

Figure 2. Diagram of PRIDE reducing supply and improving detection (Morgan \& Morgan, 2018) 
INTERNATIONAL JOURNAL OF ACADEMIC RESEARCH IN BUSINESS AND SOCIAL SCIENCES Vol. 10, No. 5, May, 2020, E-ISSN: 2222-6990 @ 2020 HRMARS

Categorization of inmates is the processes for screening women drug abuse inmates is through categorization (Laws of Malaysia, 1995) such as convict and unconvicted, drugs and non-drugs cases, and other categorization related. Whereas categorization of prison is the process separated between the main prison compound and outer compound, decided by the prison management for the community cohesion and the well-being of the offender (Laws of Malaysia, 1995). As a way for women drug abuse inmates free from any substance, conventional searching practically applied by staff for checking inmates either by pat-down search, strip search, intimate search and full-body scanning in such circumstances as the day of admission into prison, after admission, when being taken to prison from any other approved places (Laws of Malaysia, 1995). For those suspected of smuggling substances articles, they would be segregated, for a period as necessary, and if guilty, it will be referred to the police for investigation and charge in the court of law for offence of drugs possession (Laws of Malaysia, 1995). Women drug abuse inmates also require to have a urine test randomly depending on the situation for the security purpose. Rather than that detecting dog, intelligent information and inter-agency collaboration also been applied for reducing supply and improving detection as stated in the Prison Act and, the Commissioner General's Standing Order. 
INTERNATIONAL JOURNAL OF ACADEMIC RESEARCH IN BUSINESS AND SOCIAL SCIENCES

Vol. 10, No. 5, May, 2020, E-ISSN: 2222-6990 @ 2020 HRMARS

\section{Demographic Profile}

In a current study, among 150 respondents involved, the majority were Malay (66\%) followed by Indian (20.7\%), Chinese (11.3\%) while the remaining were other races (2\%). Corresponding with the race, the majority of them are Muslims (71.3\%), followed by Hindu (12.7\%), Buddhist (7.3\%), Christians (6.7\%) and, others (2\%). The majority of the respondents are between the age of 31 to 40 years (32.7\%), followed by 21 to 30 years and 41 to 50 years $(27.3 \%)$ and, more than 50 years $(12.7 \%)$. In examining the marital status, $44 \%$ were single while $20.7 \%$ were married. About $33.3 \%$ reported were widowers and, $2 \%$ were spouse dead. About $32 \%$ respondent reported that they had completed SRP/ LCE/PMR as the highest level of education. The majority of them (35.3\%) have completed SPM/MCE/SPVM. About 3.3\% have completed STPM/HSC/STAM. However, only $18 \%$ have completed primary school, and unfortunately, about $0.7 \%$ have never been to school. Only $4.7 \%$ have completed a tertiary level.

Table 1: Demographic profile of women drug abuse inmates

\begin{tabular}{|c|c|c|c|c|c|}
\hline Personal Detail & $\begin{array}{c}n \\
(150)\end{array}$ & $\begin{array}{c}\% \\
(100)\end{array}$ & Personal Detail & $\begin{array}{c}n \\
(150)\end{array}$ & $\begin{array}{c}\% \\
(100)\end{array}$ \\
\hline $\begin{array}{l}\text { Race } \\
\text { Malay } \\
\text { Chinese } \\
\text { Indian } \\
\text { Others }\end{array}$ & $\begin{array}{r}99 \\
17 \\
31 \\
3\end{array}$ & \begin{tabular}{r|}
66.0 \\
11.33 \\
20.67 \\
2.0
\end{tabular} & $\begin{array}{l}\text { Previous work } \\
\text { Unemployed } \\
\text { Self employed } \\
\text { Government } \\
\text { Private }\end{array}$ & $\begin{array}{r}10 \\
92 \\
9 \\
39\end{array}$ & $\begin{array}{r}6.67 \\
61.33 \\
6.0 \\
26.0\end{array}$ \\
\hline $\begin{array}{l}\text { Religion } \\
\text { Muslim } \\
\text { Buddhist } \\
\text { Hindu } \\
\text { Christian } \\
\text { Others }\end{array}$ & $\begin{array}{r}107 \\
11 \\
19 \\
10 \\
3\end{array}$ & \begin{tabular}{r|}
71.33 \\
7.33 \\
12.67 \\
6.67 \\
2.0
\end{tabular} & $\begin{array}{l}\text { Income (RM) } \\
<1000 \\
1001 .-2000 \\
2001-3000 \\
3001-4000 \\
>4000\end{array}$ & $\begin{array}{r}50 \\
65 \\
22 \\
9 \\
4\end{array}$ & $\begin{array}{r}33.33 \\
43.33 \\
14.67 \\
6.0 \\
2.67\end{array}$ \\
\hline \begin{tabular}{|l} 
Age \\
$21-30$ years \\
$31-40$ years \\
$41-50$ years \\
$>51$ years
\end{tabular} & $\begin{array}{l}41 \\
49 \\
41 \\
19\end{array}$ & \begin{tabular}{l|}
27.3 \\
32.7 \\
27.3 \\
12.7
\end{tabular} & $\begin{array}{l}\text { Number of incarcerations } \\
1 \text { time } \\
2-5 \text { times } \\
6-9 \text { years } \\
>10 \text { times }\end{array}$ & $\begin{array}{r}26 \\
61 \\
54 \\
9\end{array}$ & $\begin{array}{r}17.33 \\
40.67 \\
36.0 \\
6\end{array}$ \\
\hline \begin{tabular}{|l} 
Marital Status \\
Single \\
Married \\
Widower \\
Spouse died
\end{tabular} & $\begin{array}{r}66 \\
31 \\
50 \\
3\end{array}$ & $\begin{array}{r}44.0 \\
20.7 \\
33.3 \\
2.0\end{array}$ & $\begin{array}{l}\text { length of addiction } \\
1-5 \text { years } \\
6-10 \text { years } \\
11-15 \text { years } \\
>16 \text { years }\end{array}$ & \begin{tabular}{r|r}
78 \\
43 \\
20 \\
9
\end{tabular} & $\begin{array}{r}52.0 \\
28.67 \\
13.33 \\
6.0\end{array}$ \\
\hline \begin{tabular}{|l} 
Education level \\
No schooling \\
Primary school \\
SRP/ LCE/PMR \\
SPM/MCE/SPMV \\
STPM/STAM/HSC \\
Certificate level \\
Tertiary level
\end{tabular} & $\begin{array}{r}1 \\
27 \\
48 \\
53 \\
5 \\
9 \\
7\end{array}$ & \begin{tabular}{r|} 
\\
0.67 \\
18.0 \\
32.0 \\
35.33 \\
3.33 \\
6.0 \\
4.67
\end{tabular} & $\begin{array}{l}\text { Type of drug abuse } \\
\text { Opioid } \\
\text { Methamphetamine } \\
\text { Marijuana } \\
\text { Depression } \\
\text { Hallucinogen } \\
\text { Inhalant }\end{array}$ & $\begin{array}{l}92 \\
96 \\
48 \\
27 \\
16 \\
10\end{array}$ & $\begin{array}{r}61.3 \\
64.0 \\
32.0 \\
18.0 \\
10.7 \\
6.7\end{array}$ \\
\hline
\end{tabular}


For the previous work and monthly income, the majority were self-employed (61.3\%), followed by private sector (26\%) and, government (6\%). Whereas about $6.7 \%$ are unemployed. Due to the monthly income, the majority of the respondents $(43.3 \%)$ earn a monthly income between RM1001.00 to RM2000.00, followed by 33.3\% of the respondents earn less than RM1000.00. About $14.7 \%$ earn between RM2001.00 to RM3000.00, (6\%) earn between RM3001.00 to RM4000.00 and only $2.7 \%$ earn more than RM4000.00. Based on a survey, about $17.3 \%$ were first time entering prison. Meanwhile, the highest was between 2 to 5 times represented 40.67\%, followed by 6 to 9 times, $36 \%$ and, $6 \%$ for more than ten times.

Analysis of the aspects of length of addiction found that the period between 1 to 5 years represented the highest time (52\%), followed by $(28.7 \%)$ of the respondents had billed within 6 to 10 years, while the remaining (13.3\%) of the respondents had billed within 11 to 15 years. The results showed only (6\%) had been addicted to drugs in the past for more than 16 years. This long period of drug addiction is often associated with relapses where addicts find it difficult for fully recover from the effects of drugs (Azmi et al., 2018; Fitzpatrick et al., 2019; Norcross et al., 2011; Velicer et al., 1990). From the survey, the result showed that the highest type of drug abuse was methamphetamines (64\%), and closely followed by opioid (61.3\%). About 32\% misuse marijuana, $18 \%$ for depression drug, $10.7 \%$ for hallucinogen and, about $6.7 \%$ misuse inhalant. The results of this study are in contrast to the study conducted by Asmawati \& Fatimah (2005), who found that the trend of heroin drug use was a popular drug used by women drug users over the last eight years. However it was in line with a report by National Anti-Drug Agency stated that methamphetamine was the highest type of drug misuse in Malaysia (National Anti-Drugs Agency, 2017) and most significant misuse for women incarceration previously (Vik \& Ross, 2003).

\section{Level of Family Support}

The results of the study showed that the level of family support, the highest was high, $70 \%$ followed by moderate $18 \%$. It gives the impression that the family is paying attention and aware of their situation. Only $12 \%$ recorded low of family support.

\begin{tabular}{lcc}
\hline Family relationship & $\mathbf{N}=\mathbf{1 5 0}$ & $\mathbf{( \% )}$ \\
\hline Low $(<5.0)$ & 18 & 12.0 \\
Moderate $(5.01-7.5)$ & 27 & 18.0 \\
High $(7.51-10.0)$ & 105 & 70.0 \\
\hline
\end{tabular}

A family needs to give positive support to women drug abuse inmates for staying healthy in a recovery process. It based on the results of the study "my family really tries to help me" (item 1), when women drug abuse inmates in a hard time. As a result, the mean score was 8.19 and, and the most massive scale is 10 , strongly agree, representing $54.7 \%$. The result showed that the emotional support by family highly perceived by women drug abuse inmates where it showed the mean score of 7.92 (item 2 ) with the most massive scale is 10 , strongly agree, representing $44.7 \%$. Ongoing family support is essential not only during the early stages of the treatment and recovery process but throughout the recovery process. Miserable and discouraging family support is the cause of relapse (Brown et al., 
1986; Norcross et al., 2011; Takano et al., 2020). The result of this study also proved that family members often visit them at prison based on the high score of "I can talk about my problem with my family" (item 3) with the mean score of 7.91 and the most massive scale is 10, strongly agree, representing $46 \%$. The findings of this study also illustrate that excellent support, guidance provided by family members can have a positive impact of the addiction recovery process, helping improve well-being, quality of life, and psychological functioning as well helps reduce the risk of relapses (Copello et al., 2005; Mohamad, Karim, et al., 2017). It is in line with the score for item 4, "my family is willing to help me make decisions" where the most massive scale is 10 , strongly agree, $42 \%$ and the mean score is 7.61. As such, families are encouraged to remain steadfast and never hesitated to provide support to women drug abuse inmates for a better result in a recovery process.

\begin{tabular}{|ccccccccccccccc|}
\hline & \multicolumn{1}{c}{} & \multicolumn{1}{c}{ Item } & $\begin{array}{c}\mathbf{1} \\
\text { No }\end{array}$ & $\begin{array}{c}\text { Strongly } \\
\text { disagree }\end{array}$ & $\mathbf{2}$ & $\mathbf{3}$ & $\mathbf{4}$ & $\mathbf{5}$ & $\mathbf{6}$ & $\mathbf{7}$ & $\mathbf{8}$ & $\mathbf{9}$ & $\begin{array}{c}\text { 10 } \\
\text { Strongly } \\
\text { agree }\end{array}$ & mean \\
\hline 1 & My family tries to help me & 5.3 & 2.0 & 2.0 & 0.7 & 8.7 & 1.3 & 9.3 & 6.7 & 9.3 & 54.7 & 8.19 \\
& $\begin{array}{l}\text { I get the emotional help } \\
\text { and support I need from } \\
\text { my family }\end{array}$ & 6.0 & 3.3 & 1.3 & 2.0 & 6.7 & 3.3 & 8.7 & 9.3 & 14.7 & 44.7 & 7.92 \\
3 & $\begin{array}{l}\text { I can talk about my } \\
\text { problem with my family }\end{array}$ & 6.0 & 2.7 & 2.7 & 0.0 & 7.3 & 5.3 & 6.7 & 13.3 & 10.0 & 46.0 & 7.91 \\
4 & $\begin{array}{l}\text { My family is willing to } \\
\text { help me make decisions }\end{array}$ & 8.0 & 2.0 & 2.0 & 4.0 & 7.3 & 4.7 & 7.3 & 12.7 & 10.0 & 42.0 & 7.61 \\
\hline
\end{tabular}

Overall, the results of this study appeared to contradict the findings of many previous researchers. Most of previous researchers found that associate broken families, conflicts and crisis as the factors contributing to the prevalence and involvement of youth with unhealthy social symptoms such as drug abuse and alcohol (Copello et al., 2005; Kane et al., 2019; Lerner \& Galambos, 1998; Mallett et al., 2005; Schulenberg \& Maggs, 2002; Shin et al., 2019). The different findings from this study may be due to cultural differences, trends and current lifestyle changes in line with the rapidly expanding national development. Positive family relationships not only create harmony but also prevent negative behaviour tendencies (Kumpfer et al., 2003; Lewis, 2020).

\section{Conclusion}

This study had to look into PRIDE experienced in managed women drug abuse inmates. It also had described their demographic as well as analyzed the level of their family relationship. It is hope it will appear positively impacted to relevant individuals and parties such as counsellors, rehabilitation staff, social workers, students. Perhaps it also provided input value to PRIDE that are continually facing challenges in successful rehabilitation, a conducive climate and strategic integration. Additionally, the diversity of the inmates' backgrounds need to be tackled efficiently by PRIDE in term of safety and security and, rehabilitation and recovery. This current study also might provide new inputs to design and make improvements to existing security procedures and rehabilitation treatment modules. Also, it gives family institutions a unique awareness of their essential role in helping the inmates perform in their recovery process as ongoing social support from family members can prevent relapse as they 
INTERNATIONAL JOURNAL OF ACADEMIC RESEARCH IN BUSINESS AND SOCIAL SCIENCES

Vol. 10, No. 5, May, 2020, E-ISSN: 2222-6990 @ 2020 HRMARS

continue to adopt a healthier lifestyle, free from the influence of misuse drugs and help reduce the rate of recidivism among drug addicts in Malaysia.

\section{Acknowledgement}

The researchers also like to acknowledge the Malaysian Prison Department for the authorizing this research.

\section{References}

\section{Journal Article}

Alvarez, J., Olson, B. D., Jason, L. A., Davis, M. I., \& Ferrari, J. R. (2004). Heterogeneity among Latinas and Latinos entering substance abuse treatment: Findings from a national database. Journal of Substance Abuse Treatment, 26(4), 277-284. https://doi.org/10.1016/j.jsat.2004.02.003

Austin, J., Bloom, B., \& Donahue, T. (1992). THESIS Female offenders in the community: An analysis of innovative strategies and programs. ... DC: National Institute of Corrections, 90.

Azmi, A. A., Hussin, H., Ishak, S. I. Di., \& Daud-Fhiri, N. S. (2018). Drug Addicts: Psychosocial Factor Contributing to Relapse. MATEC Web of Conferences, 150, 1-6. https://doi.org/10.1051/matecconf/201815005097

Back, S. E., Payne, R. L., Wahlquist, A. H., Carter, R. E., Stroud, Z., Haynes, L., Hillhouse, M., Brady, K. T., \& Ling, W. (2011). Comparative profiles of men and women with opioid dependence: Results from a national multisite effectiveness trial. American Journal of Drug and Alcohol Abuse, 37(5), 313-323. https://doi.org/10.3109/00952990.2011.596982

Basir, N. (2002). Female Criminality: A Case Study of Women Inmates in Kajang Prison, Selangor, Malaysia. International Islamic University Malaysia., 1-24.

Birkeland, M. S., Blix, I., Solberg, $\varnothing ., \&$ Heir, T. (2017). Gender differences in posttraumatic stress symptoms after a terrorist attack: A network approach. Frontiers in Psychology, 8(DEC), 1-11. https://doi.org/10.3389/fpsyg.2017.02091

Boyas, J. F., Villarreal-Otálora, T., \& \& Marsiglia, F. F. (2019). Alcohol Use among Latinx Early Adolescents: Exploring the Role of the Family. Journal of Alcohol and Drug Education, 63(2).

Brady, K. T., Dansky, B. S., Sonne, S. C., \& Saladin, M. E. (1998). Posttraumatic stress disorder and cocaine dependence: Order of onset. American Journal on Addictions, 7(2), 128-135. https://doi.org/10.3109/10550499809034484

Brannigan, A., Gemmell, W., Pevalin, D. J., \& Wade, T. J. (2002). Self-control and social control in childhood misconduct and aggression: The role of family structure, hyperactivity, and hostile parenting. Canadian Journal of Criminology, 44(2), 119-142.

Bremer-Landau, J. D., \& Caskie, G. I. L. (2019). Gender as Potential Moderator of Associations Among Trauma Exposure, Posttraumatic Stress Disorder Symptoms, and Alcohol Use Disorder Symptoms in Young Adults. Journal of Traumatic Stress, 32(4), 586-594. https://doi.org/10.1002/jts.22419

Brown, S. A., Vik, P. W., Patterson, T. L., \& Grant, I. (1986). Vulnerability and Adult Alcohol Relapse. Journal of Studies on Alcohol, 56(5), 538-545.

Chatham, L. R., Hiller, M. L., Rowan-Szal, G. A., Joe, G. W., \& Simpson, D. D. (1999). Gender differences at admission and follow-up in a sample of methadone maintenance clients. Substance Use and Misuse, 34(8), 1137-1165. https://doi.org/10.3109/10826089909039401

Chie, Q. T., Tam, C. L., Bonn, G., Wong, C. P., Dang, H. M., \& Khairuddin, R. (2015). Drug abuse, relapse, 
INTERNATIONAL JOURNAL OF ACADEMIC RESEARCH IN BUSINESS AND SOCIAL SCIENCES

Vol. 10, No. 5, May, 2020, E-ISSN: 2222-6990 @ 2020 HRMARS

and prevention education in Malaysia: Perspective of university students through a mixed methods approach. Frontiers in Psychiatry, 6(MAY). https://doi.org/10.3389/fpsyt.2015.00065

Copello, A. G., Velleman, R. D. B., \& Templeton, L. J. (2005). Family interventions in the treatment of alcohol and drug problems. Drug and Alcohol Review, 24(4), 369-385. https://doi.org/10.1080/09595230500302356

Cormier, R. A., Dell, C. A., \& Poole, N. (2004). Women and Substance Abuse Problems. BMC Women's Health, 4(Suppl 1), S8. https://doi.org/10.1186/1472-6874-4-s1-s8

Dakir, J., Tibek, S. R., Hamjah, S. H., \& Mohamad, R. (2015). Program koreksi berasaskan islam melalui program halaqah sebagai medium dakwah kepada banduan di penjara Kajang. Jurnal Al-Hikmah, 7(2), 3-22.

Davis, S. K. (1990). Chemical dependency in women: A description of its effects and outcome on adequate parenting. Journal of Substance Abuse Treatment, 7(4), 225-232. https://doi.org/10.1016/0740-5472(90)90045-R

De Leon, G., \& Jainchill, N. (1991). Residential therapeutic communities for female substance abusers. Bulletin of the New York Academy of Medicine: Journal of Urban Health, 67(3), 277-290.

Eliason, M. J. (2006). Are therapeutic communities therapeutic for women? Substance Abuse: Treatment, Prevention, and Policy, 1(1), 1-7. https://doi.org/10.1186/1747-597X-1-3

Embleton, L., Atwoli, L., Ayuku, D., \& Braitstein, P. (2013). The Journey of Addiction: Barriers to and Facilitators of Drug Use Cessation among Street Children and Youths in Western Kenya. PLoS ONE, 8(1). https://doi.org/10.1371/journal.pone.0053435

Farrow, J. A., \& French, J. (1986). The drug abuse-deliquency connection revisited. Libra Publishers, Inc.

Fauziah, I., Khadijah, A., Noremy, M. A., Samon, N., \&, \& Lukman, Z. M. (2012). The Role of Family Towards Current Adolescence Challenges Drug Prevention and Living Without Drugs. Social Sci, 7, 341-345.

Fazillah, A., Juahir, H., Toriman, E., Mohamad, N., Kamarudin, M. K. A., Fairuz, A., Omar, S. M. H. S., Adi-Ana, G., \& Mohamad, M. (2018). Family support indices for substance abuser in Terengganu. International Journal of Engineering and Technology(UAE), 7(4), 2655-2662. https://doi.org/10.14419/ijet.v7i4.10452

Fazly, B., Ahmad, B., \& Committee, H. D. (2019). Socio-Economic Factors Influencing Relapse Among Rehabilitated Adult Female Drug Users in Kabul , Afghanistan. September.

Fehrmann, S. E. (2019). Female Prison Experience. The Encyclopedia of Women and Crime, 1-5. https://doi.org/10.1002/9781118929803.ewac0165

Fitzpatrick, C. J., Geary, T., Creeden, J. F., \& Morrow, J. D. (2019). Sign-tracking behavior is difficult to extinguish and resistant to multiple cognitive enhancers. Neurobiology of Learning and Memory, 163(January), 107045. https://doi.org/10.1016/j.nlm.2019.107045

Foster, A. M., Armstrong, J., Buckley, A., Sherry, J., Young, T., Foliaki, S., James-Hohaia, T. M., Theadom, A., \& McPherson, K. M. (2012). Encouraging family engagement in the rehabilitation process: A rehabilitation provider's development of support strategies for family members of people with traumatic brain injury. Disability and Rehabilitation, 34(22), 1855-1862. https://doi.org/10.3109/09638288.2012.670028

Goncharenko, S., Weiss, N. H., Contractor, A. A., Dixon-Gordon, K. L., \& Forkus, S. R. (2019). The role of gender in the associations among posttraumatic stress disorder symptom, severity, difficulties regulating emotions, and alcohol misuse. Addictive Behaviors, 99(August), 106086. 
INTERNATIONAL JOURNAL OF ACADEMIC RESEARCH IN BUSINESS AND SOCIAL SCIENCES

Vol. 10, No. 5, May, 2020, E-ISSN: 2222-6990 @ 2020 HRMARS

https://doi.org/10.1016/j.addbeh.2019.106086

Greenfield, S. F., Brooks, A. J., Gordon, S. M., Green, C. A., Kropp, F., McHugh, R. K., Lincoln, M., Hien, D., \& Miele, G. M. (2007). Substance abuse treatment entry, retention, and outcome in women: A review of the literature. Drug and Alcohol Dependence, 86(1), 1-21. https://doi.org/10.1016/j.drugalcdep.2006.05.012

Grella, C. E., Scott, C. K., Foss, M. A., \& Dennis, M. L. (2008). Gender similarities and differences in the treatment, relapse, and recovery cycle. Evaluation Review, 32(1), 113-137. https://doi.org/10.1177/0193841X07307318

Harrison, L., \& Gfroerer, J. (1992). The intersection of drug use and criminal behavior : result from the national household survey on drug abuse. Hispanic Journal of Behavioral Sciences, 9(2), 183205. https://doi.org/10.1177/07399863870092005

Hashim, H., Zakiyy, N., Chiang, C. J.-T., \& Rajamanikam, R. (2018). Program pemulihan di dalam penjara bagi pesalah jenayah: kajian di Jabatan Penjara Malaysia (prison rehabilitation programme for criminal offenders : a study in Malaysian Prison Department ). JUUM (Special Issue), 72-85.

Herrera, V. M., \& McCloskey, L. A. (2003). Sexual abuse, family violence, and female delinquency: Findings from a longitudinal study. Violence \& Victims 18(3), 309:334.

Hussin, F., Ali, J., \&, \& Noor, M. S. Z. (2014). Kaedah penyelidikan \& analisis data SPSS. Universiti Utara Malaysia Press.

Ibrahim, K. U. A. (2011). Isu dalam penahanan dan pemulihan banduan di malaysia 1. April, 143-168. Jabatan Penjara Malaysia. (2020). Statistik banduan / tahanan / penghuni harian SMPP.

Kane, J. C., Johnson, R. M., Iwamoto, D. K., Jernigan, D. H., Harachi, T. W., \& Bass, J. K. (2019). Pathways linking intergenerational cultural dissonance and alcohol use among Asian American youth: The role of family conflict, parental involvement, and peer behavior. Journal of Ethnicity in Substance Abuse, 18(4), 613-633. https://doi.org/10.1080/15332640.2018.1428709

Keen, J. (2000). Keeping families of heroin addicts together: results of 13 months' intake for community detoxification and rehabilitation at a family centre for drug users. Family Practice, 17(6), 484-489. https://doi.org/10.1093/fampra/17.6.484

Kendler, K. S., Ohlsson, H., Sundquist, J., \& Sundquist, K. (2019). Contagion models for the transmission of drug abuse among propinquity-of-rearing defined acquaintances: A Swedish national study. Drug and Alcohol Dependence, 201(June), 94-100. https://doi.org/10.1016/j.drugalcdep.2019.03.027

King, R. D. (1991). Maximum-security custody in Britain and the USA: A study of gartree and oak park heights. British Journal of Criminology, 31(2), 126-152. https://doi.org/10.1093/oxfordjournals.bjc.a048094

Kumpfer, K. L., Alvarado, R., Whiteside, H. O. (2003). Family-Based Interventions for Substance Use and Misuse Prevention \#. 38(801), 1759-1787. https://doi.org/10.1081/JA-120024240

Lal, R., Deb, K. S., \& Kedia, S. (2015). Substance use in women: Current status and future directions. Indian Journal of Psychiatry, 57(July 2015), 275-285. https://doi.org/10.4103/00195545.161491

Laws of Malaysia. (1995). Prison Act 1995 (Issue October). The commissioner of law revision, Malaysia.

Lerner, R. M., \& Galambos, N. L. (1998). ADOLESCENT DEVELOPMENT: Challenges and Opportunities for Research, Programs, and Policies. Annual Review of Psychology, 49(1), 413-446. 
INTERNATIONAL JOURNAL OF ACADEMIC RESEARCH IN BUSINESS AND SOCIAL SCIENCES

Vol. 10, No. 5, May, 2020, E-ISSN: 2222-6990 @ 2020 HRMARS

https://doi.org/10.1146/annurev.psych.49.1.413

Lewis, A. J. (2020). Attachment-Based Family Therapy for Adolescent Substance Use : A Move to the Level of Systems. 10(February), 1-10. https://doi.org/10.3389/fpsyt.2019.00948

Malaysia Prison Department. (2012). Welcome to the Malaysian Prison Department Official Portal. http://www.prison.gov.my/portal/page/portal/english

Malhotra, N., Hall, J., Shaw, M., \& Oppenheim, P. (2007). Marketing research: An applied orientation. Pearson Education/Practice Hall.

Mallett, S., Rosenthal, D., \& Keys, D. (2005). Young people, drug use and family conflict: Pathways into homelessness. Journal of Adolescence, 28(2 SPEC. ISSS.), 185-199.

https://doi.org/10.1016/j.adolescence.2005.02.002

Mann, K., Hintz, T., \& Jung, M. (2004). Does psychiatric comorbidity in alcohol-dependent patients affect treatment outcome? European Archives of Psychiatry and Clinical Neuroscience, 254(3), 172-181. https://doi.org/10.1007/s00406-004-0465-6

Mendelsohn, M., \& Sewell, K. W. (2004). Social attitudes toward traumatized men and women: A vignette study. Journal of Traumatic Stress, 17(2), 103-111.

https://doi.org/10.1023/B:JOTS.0000022616.03662.2f

Mohamad, M., Afthanorhan, A., Awang, Z., \& Mohammad, M. (2019). Comparison between CB-SEM and PLS-SEM: Testing and confirming the Maqasid Syariah quality of life measurement model. Journal of Social Sciences Research, 5(3), 608-614. https://doi.org/10.32861/jssr.53.608.614

Mohamad, M., Karim, F., Ali, N., \& Mohamed, H. (2017). A Conceptual Model of Perceived Social Support, Maqasid Shariah Quality of Life and Health Status. In Research Journal of Medical Sciences (Vol. 11, Issue 1, pp. 62-68).

Mohamad, M., Ali, M. N. A., \& Muhammad, N. (2017). Measurement of Drug-abuse Inmates 'Prison Climate : Confirmatory Factor Analysis. International Journal of Applied Business and Economic Research, 15(25), 405-421.

Mohamad, M., Mohammad, M., Ali, M. N. A., \& Awang, Z. (2018). The impact of life satisfaction on substance abuse: delinquency as a mediator. International Journal of Adolescence and Youth, 23(1), 25-35. https://doi.org/10.1080/02673843.2016.1267021

Nor, M. S. N., Kamaluddin, M. R., \& Sulaiman, W. S. (2019). Profil Jenayah Banduan Wanita di Malaysia: Satu Kajian Kualitatif (Criminal Profile of Female Prisoners in Malaysia: A Qualitative Study). Akademika, 89(2), 43-56. http://ejournal.ukm.my/akademika/article/view/25032/9680

Moran, R., O'brien, M., Dillon, L., Farrell., \& Mayock, P. (2001). Overview of drug issues in Ireland 2000: a resource document. http://hdl.handle.net/10147/338537Findthisandsimilarworksathttp://www.lenus.ie/hse

Morgan, R., \& Morgan, N. (2018). 38 th Asian and Pacific Conference of Correctional Administrators (APPCA).

National Anti-Drugs Agency. (2017). Maklumat dadah 2017. Kementerian Dalam Negeri, 7-12, 31. https://www.adk.gov.my/wp-content/uploads/Maklumat-Dadah-2017_final-compressed.pdf

National Institute on Drug Abuse. (2016). Drugfacts: Treatment approaches for drug addiction. NIDA. http://www.drugabuse.gov

Norcross, J. C., Krebs, P. M., \& Prochaska, J. O. (2011). Stages of change. Journal of Clinical Psychology, 67(2), 143-154. https://doi.org/10.1002/jclp.20758

Ornoy, A., Daka, L., Goldzweig, G., Gil, Y., Mjen, L., Levit, S., Shufman, E., Bar-Hamburger, R., \& Greenbaum, C. W. (2010). Neurodevelopmental and psychological assessment of adolescents 
INTERNATIONAL JOURNAL OF ACADEMIC RESEARCH IN BUSINESS AND SOCIAL SCIENCES

Vol. 10, No. 5, May, 2020, E-ISSN: 2222-6990 @ 2020 HRMARS

born to drug-addicted parents: Effects of SES and adoption. Child Abuse and Neglect, 34(5), 354368. https://doi.org/10.1016/j.chiabu.2009.09.012

Possick, C., \& Itzick, M. (2018). Women's Experience of Drug Abuse Treatment in a Mixed-Gender Therapeutic Community. Affilia - Journal of Women and Social Work, 33(4), 493-508. https://doi.org/10.1177/0886109918766674

Putkonen, H., Komulainen, E. J., Virkkunen, M., M., E., \& \& Lonnqvist, J. (2003). Risk of repeat offending among violent female offenders with psychotic and personality disorders. American Journal of Psychiatry 160(5), 947-951.

Ronzitti, S., Loree, A. M., Potenza, M. N., Decker, S. E., Wilson, S. M., Abel, E. A., Haskell, S. G., Brandt, C. A., \& Goulet, J. L. (2019). Gender Differences in Suicide and Self-Directed Violence Risk Among Veterans With Post-traumatic Stress and Substance Use Disorders. Women's Health Issues, 29, S94-S102. https://doi.org/10.1016/j.whi.2019.04.010

SAMHSA. (1999). Center for Substance Abuse Treatment. Brief Interventions and Brief Therapies for Substance Abuse. Treatment Improvement Protocol (TIP). HHS Publication.

Schulenberg, J. E., \& Maggs, J. L. (2002). A developmental perspective on alcohol use and heavy drinking during adolescence and the transition to young adulthood. Journal of Studies on Alcohol, 63(SUPPL. 14), 54-70. https://doi.org/10.15288/jsas.2002.s14.54

Shin, Y. J., Miller-Day, M., \& Hecht, M. L. (2019). Differential Effects of Parental "drug talk" Styles and Family Communication Environments on Adolescent Substance Use. Health Communication, 34(8), 872-880. https://doi.org/10.1080/10410236.2018.1439268

Stevens, D. J. (1997). Prison Regime and Drugs. The Howard Journal of Criminal Justice, 36(1), 14-27. https://doi.org/10.1111/1468-2311.00036

Takano, A., Miyamoto, Y., Shinozaki, T., Matsumoto, T., \& Kawakami, N. (2020). Effect of a web-based relapse prevention program on abstinence among Japanese drug users: A pilot randomized controlled trial. Journal of Substance Abuse Treatment, 111, 37-46. https://doi.org/10.1016/j.jsat.2019.12.001

Toner, P., \& Velleman, R. (2014). Initial reliability and validity of a new measure of perceived social support for family members of problem substance users. Addiction Research and Theory, 22(2), 147-157. https://doi.org/10.3109/16066359.2013.779675

Velicer, W. F., Diclemente, C. C., Rossi, J. S., \& Prochaska, J. O. (1990). Relapse situations and selfefficacy: An integrative model. Addictive Behaviors, 15(3), 271-283. https://doi.org/10.1016/0306-4603(90)90070-E

Vik, P. W., \& Ross, T. (2003). Methamphetamine use among incarcerated women. Journal of Substance Use, 8(2), 69-77. https://doi.org/10.1080/1465989031000109806

Visher, C. A., Debus-Sherrill, S. A., \& Yahner, J. (2011). Employment after prison: A longitudinal study of former prisoners. Justice Quarterly, 28(5), 698-718. https://doi.org/10.1080/07418825.2010.535553

Walmsley, R. (2015). World female imprisonment list: Fourth edition, women and girls in penal institutions, including pre-trial detainees/remand prisoners. World Prison Brief, 1-13. http://www.prisonstudies.org/news/more-700000-women-and-girls-are-prison-around-worldnew-report-shows

Wilson, J. Q., \& Kelling, G. L. (1982). The police and neighborhood safety. The Atlantic Monthly, March(March), 29-38. http://www.theatlantic.com/doc/print/198203/broken-windows

Zimet, \& Gregory. (2016). Multidimensional Scale of Perceived Social Support (MSPSS) - Scale Items 
INTERNATIONAL JOURNAL OF ACADEMIC RESEARCH IN BUSINESS AND SOCIAL SCIENCES

Vol. 10, No. 5, May, 2020, E-ISSN: 2222-6990 @ 2020 HRMARS

and Scoring Information. December, 3-5.

Zimmer-Gembeck, M. J., \& Geiger, T. A., \& Crick, N. R. (2005). Relational and physical aggression, prosocial behavior and peer relations: Gender moderation and bidirectional associations. Journal of Early Adolescence 25, 421-452.

Zimmermann, G., Pin, M. A., Krenz, S., Bouchat, A., Favrat, B., Besson, J., \& Zullino, D. F. (2004). Prevalence of social phobia in a clinical sample of drug dependent patients. Journal of Affective Disorders, 83(1), 83-87. https://doi.org/10.1016/j.jad.2004.05.003

\section{Book}

Commissioner, T. H. E., \& Law, O. F. (2009). Act 537 Prison Act 1995.

Hussin, F., Ali, J., \&, \& Noor, M. S. Z. (2014). Kaedah penyelidikan \& analisis data SPSS. Universiti Utara Malaysia Press.

Malhotra, N., Hall, J., Shaw, M., \& Oppenheim, P. (2006). Marketing research: An applied orientation. Pearson Education.

Substance Abuse and Mental Health Services Administration. (1999). Center for Substance Abuse Treatment. Brief Interventions and Brief Therapies for Substance Abuse. Treatment Improvement Protocol (TIP). HHS Publication.

Wilson, J. Q., \& Kelling, G. L. (1982). The police and neighbourhood safety. The Atlantic Monthly, March (March), 29-38. http://www.theatlantic.com/doc/print/198203/broken-windows

\section{Online Official Websites}

Malaysia Prison Department. (2012). Welcome to the Malaysian Prison Department Official Portal. http://www.prison.gov.my/portal/page/portal/english

National Anti-Drugs Agency. (2017). Maklumat dadah, 2017. Kementerian Dalam Negeri, 7-12, 31. https://www.adk.gov.my/wp-content/uploads/Maklumat-Dadah-2017_final-compressed.pdf

National Institute on Drug Abuse. (2016). Drug facts: Treatment approaches for drug addiction. NIDA. http://www.drugabuse.gov

\section{Encyclopedia Articles}

Fehrmann, S. E. (2019). Female Prison Experience. The Encyclopedia of Women and Crime, 1-5. https://doi.org/10.1002/9781118929803.ewac0165

\section{Technical and Research Reports (often with corporate authors)}

Austin, J., Bloom, B., \& Donahue, T. (1992). Female offenders in the community: An analysis of innovative strategies and programs.DC: National Institute of Corrections, 90.

Basir, N. (2002). Female Criminality: A Case Study of Women Inmates in Kajang Prison, Selangor, Malaysia. International Islamic University Malaysia., 1-24

Fazly, B., Ahmad, B., \& Committee, H. D. (2019). Socio-Economic Factors Influencing Relapse Among Rehabilitated Adult Female Drug Users in Kabul, Afghanistan. September.

Hashim, H. (2018). Program Pemulihan di dalam Penjara bagi Pesalah Jenayah : Kajian di Jabatan Penjara Malaysia ( Prison Rehabilitation Programme for Criminal Offenders: A Study in Malaysian Prison Department ). 72-85.

Ibrahim, K. U. A. (2011). Isu dalam penahanan dan pemulihan banduan di malaysia 1. April, 143-168. Jabatan Penjara Malaysia. (2020). Statistik Banduan/Tahanan/Penghuni Harian SMPP. 
INTERNATIONAL JOURNAL OF ACADEMIC RESEARCH IN BUSINESS AND SOCIAL SCIENCES

Vol. 10, No. 5, May, 2020, E-ISSN: 2222-6990 @ 2020 HRMARS

Moran, R., O’brien, M., Dillon, L., Farrell, \& Mayock, P. (2001). Overview of drug issues in Ireland 2000: a resource document.

Morgan, N. (2018). 38th the Asian and Pacific Conference of Correctional Administrators Melaka, Malaysia.

Walmsley, R. (2017). World female imprisonment list: Fourth edition, women and girls in penal institutions, including pre-trial detainees/remand prisoners. World Prison Brief, 1-13. http://www.prisonstudies.org/news/world-female-imprisonment-list-fourth-edition 